\title{
MODULATION OF CONA-INDUCED INFLAMMATORY ASCITES BY HISTAMINE - SHORT COMMUNICATION
}

\author{
KÁROLY BAINTNER*
}

(Received: 10 January 2015; accepted: 5 February 2015)

\begin{abstract}
The early phase of the ConA-induced inflammatory ascites was studied, with special reference to histamine. Concanavalin A (ConA), a cell-surface binding lectin was injected i.p. $(25 \mathrm{mg} / \mathrm{kg} \mathrm{bw})$ to mice. After $1 \mathrm{~h}$ the animals were killed, the ascitic fluid collected and measured. Other agents were injected s.c., 10 min before the ConA-challenge. Exogenous histamine markedly inhibited the ConA-induced ascites. Release of endogenous vasoactive agents from the mast cells by Compound 48/80 had a similar, but slight effect. Cromolyn, a mast cell stabilizing agent, and chloropyramine, a histamine $\mathrm{H} 1$ receptor antagonist was ineffective. Although histamine increases endothelial permeability, it did not enhance the formation of ascitic fluid, on the contrary, it inhibited the ConA-induced ascites, presumably due to its known hypotonic effect. It is concluded that ConA-induced ascites is not mediated by mast cell histamine.
\end{abstract}

Keywords: histamine, ConA, ascites, mast cell, cromolyn, chloropyramine

\section{Introduction}

Earlier experiments [1] showed that non-covalent cross-linking of cellsurface glycoproteins by plant lectins or polykationic macromolecules induces accumulation of inflammatory (protein-rich) ascitic fluid in the peritoneal cavity still before the major influx of leukocytes [2]. However, the cellular mediation of ascites formation has remained unexplored.

Concanavalin A (ConA) is a plant lectin which recognizes $\alpha$-mannosyl residues in complex glycosyl side chains of cell surface glycoproteins. If injected into the abdominal cavity, ConA binds to the mesothelial lining [3], mast cells [4-6] and leukocytes [7].

*E-mail: rakiab22@gmail.com 
In the present experiments ConA was used for the induction of ascites, and the modulation by exogenous or mast cell histamine was investigated. The role of macrophages and the mesothelial lining in the mediation of ascites will be dealt with in another paper.

\section{Materials and Methods}

\section{Chemicals}

ConA was Sigma L7647, type VI. Chloropyramine Cl (Suprastin inj. ${ }^{\mathrm{TM}}$ ) was a commercial product and the other chemicals were bought from Sigma.

\section{Animals and protocol}

Female NMRI mice (24 to $25 \mathrm{~g}$, Charles River) were used in groups of 6. The experiments complied with the Hungarian Animal Welfare Act XVIII/1998 and Edict 243/1998 and were approved by the local ethical committee and the Veterinary Office of Somogy County.

ConA (25 mg/kg bw) was dissolved in physiological saline and injected intraperitoneally to mice in $0.1 \mathrm{ml}$ volume. After $1 \mathrm{~h}$ the animals were decapitated under ether anesthesia, the abdomen was opened and the ascitic fluid carefully collected. The volume was measured by pipetting the fluid into another tube and was expressed as $\%$ of body weight.

Histamine, Compound 48/80 and sodium cromoglycate (cromolyn) was dissolved in physiological saline and injected s.c. to mice in $0.1 \mathrm{ml}$ volume, 10 minutes before the Con A challenge. Histamine was neutralized with $\mathrm{HCl}$ before use and the site of s.c. injection was treated locally with lidocaine.

Negative control groups were treated with i.p. Compound $48 / 80$ or physiological saline $(0.1 \mathrm{ml})$ for $1 \mathrm{~h}$.

\section{Statistics}

Significance of differences was calculated with one-way ANOVA using the SPSS program. 


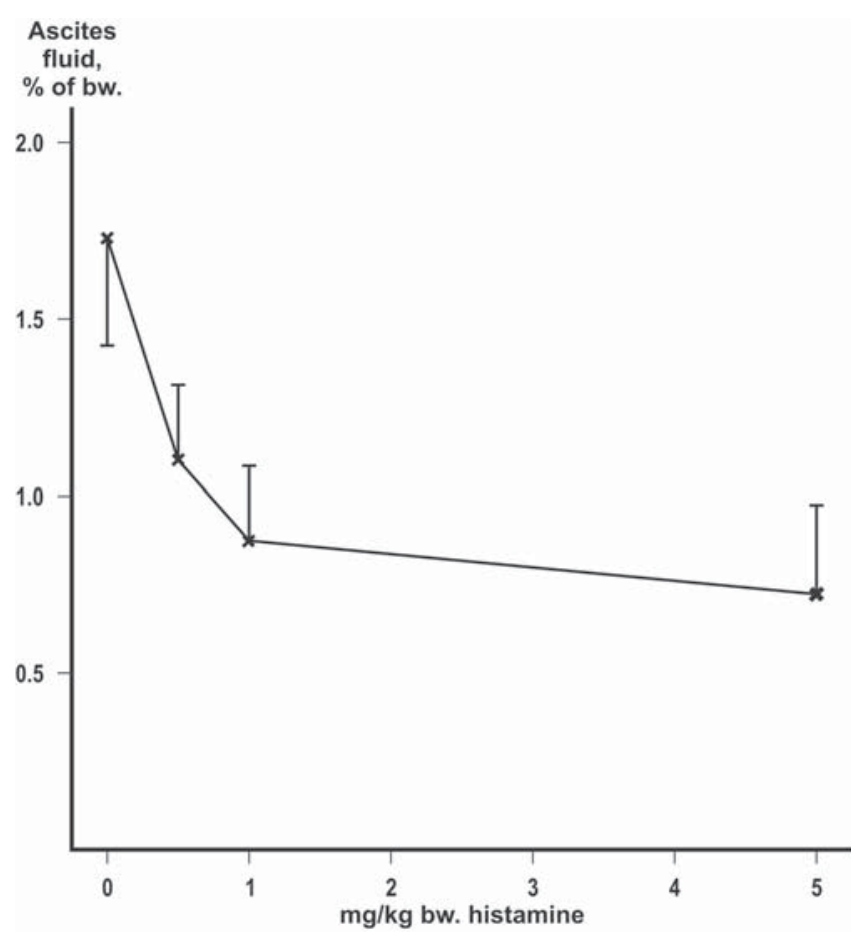

Figure 1. Effect of pre-treatment with different doses of histamine (s.c.) on ConA-induced ascites (i.p., $25 \mathrm{mg} / \mathrm{kg}$ bw, $1 \mathrm{~h}$ ). Mean $\pm \mathrm{SD}, \mathrm{n}=6$

\section{Results}

The effect of exogenous histamine on the ConA-induced ascites

Exogenous histamine significantly $(p<0.01)$ suppressed the ConA-induced ascites (Fig. 1) as compared to the positive control (ConA alone). The effect was dose-dependent, but complete inhibition could not be achieved.

ConA-induced ascites as affected by the functional state of mast cells

S.c. administration of Compound 48/80 (1.5 mg/kg bw) significantly ( $p<$ 0.05 ) inhibited the ascites formation as compared to the positive control group (i.p. ConA alone), whereas the groups treated with $\mathrm{Na}$ cromoglycate (cromolyn, $60 \mathrm{mg} / \mathrm{kg} \mathrm{bw})$ or chloropyramine chloride $(4 \mathrm{mg} / \mathrm{kg} \mathrm{bw})$ did not differ significantly (Fig. 2). 
Ascites fluid, $\%$ of bw.

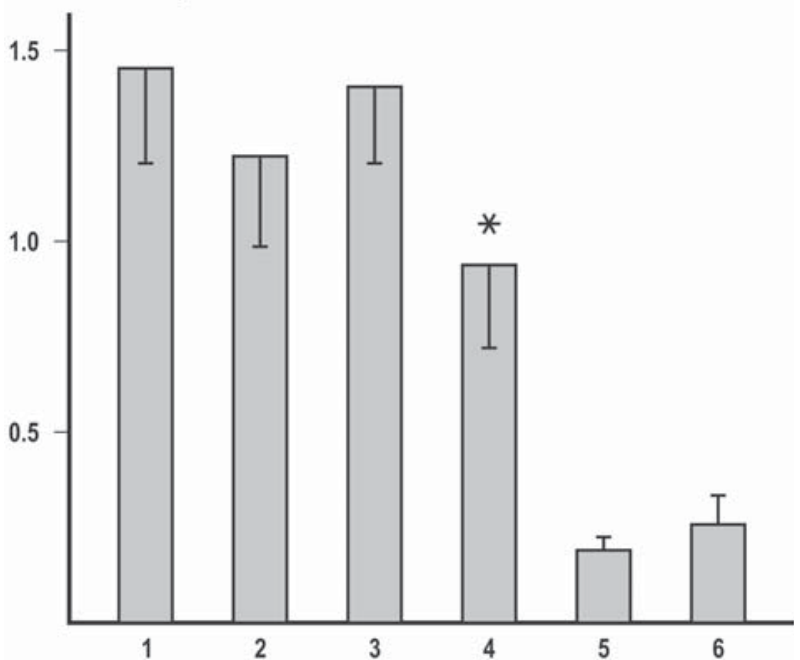

Figure 2. ConA-induced ascites as affected by the functional state of mast cells

$$
\begin{aligned}
& \text { Mean } \pm \mathrm{SD}, \mathrm{n}=6 \text {. The asterisk indicates significant }(p<0.05) \text { difference } \\
& \text { 1: } \text { I.p. ConA, positive control } \\
& \text { 2: } \text { S.c. chloropyramine and i.p. ConA } \\
& \text { 3: } \text { S.c. cromoglycate and i.p. ConA } \\
& \text { 4: } \text { S.c. Compound } 48 / 80 \text { and i.p. ConA } \\
& \text { 5: I.p. Compound } 48 / 80 \text { alone } \\
& \text { 6: Physiological saline, negative control }
\end{aligned}
$$

When Compound 48/80 was injected i.p. as a control $(1.5 \mathrm{mg} / \mathrm{kg}$ bw, without ConA-challenge), the volume of the peritoneal fluid did not differ significantly from that of the saline-treated animals (Fig. 2).

\section{Discussion}

Mast cell histamine, being a vasoactive agent, was considered a possible mediator of ConA-induced ascites. However, ascites could not be enhanced by the s.c. administration of histamine, on the contrary, it markedly inhibited it (Fig. 1), presumably due to its known hypotonic effect.

In a second experimental series the release of endogenous histamine by treatment with Compound 48/80 slightly, but significantly $(p<0.05)$ suppressed the volume of ConA-induced ascites (Fig. 2). The mast cell stabilizer cromolyn [8] and the $\mathrm{H} 1$ receptor antagonist chloropyramine were ineffective in our experimental arrangement (Fig. 2). 
During peritoneal dialysis, permeability appears to be regulated by the vascular endothelium and not by the layer of the mesothelial cells [9-10]. It is also known that histamine increases the permeability of the venous endothelium [11-12]. Mast cells produce several agents together with histamine. However, both exogenous histamine and mast cell degranulation counteracted the ConAinduced ascites.

\section{Acknowledgement}

This work was supported by the OTKA T 43541 grant.

\section{References}

1. Baintner, K.: Inflammatory ascites formation induced by macromolecules in mice and rats. Am J Physiol, Regul Integr Comp Physiol 296, R218-R223 (2009).

2. Baintner, K., Bodnár, Zs., Kiss, P., L. Kiss, A., Lukáts, Á.: Effect of intraperitoneally administered plant lectins on leukocyte diapedesis and visceral organ weight in rats and mice. Pathol Oncol Res 13, 139-143 (2007).

3. Roth, J.: Ultrahistochemical demonstration of saccharide components of complex carbohydrates at the alveolar cell surface and at the mesothelial cell surface of the pleura visceralis of mice by means of concanavalin A. Exp Pathol (Jena) 8, 157-167 (1973).

4. Hook, W.A., Dougherty, S.F., Oppenheim, J.J.: Release of histamine from hamster mast cells by concanavalin A and phytohemagglutinin. Infect Immun 9, 903-908 (1974).

5. Bach, M.K., Brashler, J.R.: Inhibition of IgE and compound 48/80-induced histamine release by lectins. Immunology 29, 371-386 (1975).

6. Sullivan, T.J., Greene, W.C., Parker, C.W.: Concanavalin A-induced histamine release from normal rat mast cells. J Immunol 115, 278-282 (1975).

7. Takata, K., Hirano, H.: Whole-cell-mount cytochemistry by the colloidal gold labeling method. Combined transmission and scanning electron microscopic study of ConA binding sites in mouse macrophages. Histochemistry 81, 435-439 (1984).

8. Theoharides, T.C., Sieghart, W., Greengard, P., Douglas, W.W.: Antiallergic drug cromolyn may inhibit histamine secretion by regulating phosphorylation of a mast cell protein. Science 207, 80-82 (1980).

9. Flessner, M.F.: The transport barrier in intraperitoneal therapy. Am J Renal Physiol 288, F433-F442 (2005).

10. Flessner, M.F.: Endothelial glycocalyx and the peritoneal barrier. Perit. Dial. Int. 28, 6-12 (2008).

11. Feng, D., Nagy, J.A., Hipp, J., Dvorak, H.F., Dvorak, A.M.: Vesiculo-vacuolar organelles and the regulation of venule permeability to macromolecules by vascular permeability factor, histamine and serotonin. J Exp Med 183, 1981-1986 (1996).

12. Wu. N.Z., Baldwin, A.L.: Transient venular permeability increase and endothelial gap formation induced by histamine. Am J Physiol 262, H1238-H1247 (1992). 